\title{
Application of Pretreatments on Banana Slices for Improving Drying Characteristics
}

\author{
Aijaz Hussain Soomro ${ }^{1 *} \quad$ Tahseen Fatima Miano $^{1} \quad$ Asadullah Marri $^{1} \quad$ Dileep Kumar ${ }^{1}$ \\ Shazor Gul Khaskheli ${ }^{1} \quad$ Umair Farooque Arain ${ }^{1} \quad$ Allah Bux Baloch ${ }^{1}$ \\ Institute of Food Sciences and Technology, Sindh Agriculture University, 70060, Tandojam, Sindh, \\ Pakistan
}

\begin{abstract}
The banana slices were subjected to pretreatment solutions for improving drying, physico-chemical and sensory characteristics. The pretreatments were applied with four different solutions including ascorbic acid, lemon juice, sodium chloride and honey. The banana slices were cut into $5 \mathrm{~mm}$ and $7 \mathrm{~mm}$ in size, about $120 \mathrm{~g}$ banana slice samples were dip in each pretreatment solution for ten min. The banana slice samples were dehydrated in dehydration chamber and dried at temperatures of $60^{\circ} \mathrm{C}$ for 12 to $16 \mathrm{hrs}$. Each sample was observed for physico chemical characteristics such as $\mathrm{pH}$, TSS, vitamin $\mathrm{C}$, total sugar and ash \% and sensory analysis of their color, aroma, taste, texture and overall acceptability were observed. The results obtained showed that the banana slices treated with ascorbic acid and honey solution has the highest value of vitamin C. The results obtained for sensory analysis showed the significant difference in aroma, taste, texture and overall acceptability scores recorded for the samples pretreated with honey solutions for ten min. It is concluded from the present study that pretreatment solutions have important role in determining the final quality characteristics of dried banana slices and it has great potential application in food industries.
\end{abstract}

Keywords: Banana; slices; pretreatment; ascorbic acid, honey, drying characteristics; sensory evaluation.

DOI: $10.7176 / \mathrm{FSQM} / 103-06$

Publication date: December $31^{\text {st }} 2020$

\section{Introduction}

Banana (Musa cavendish L.) of Musaceae family has been grown all around the world. Bananas are good source of carbohydrates, vitamin $\mathrm{B}_{6}$, soluble fiber, vitamin $\mathrm{C}$, manganese, and potassium. It has been recognized from research that when banana consumed along with other fruits and vegetables, they help in reducing the hazard of cancer and other diseases (Pellegrini et al., 1996). In Pakistan, the production of banana is approximately 154000 tons (GoP, 2011). The ripened banana contains moisture content 80 percentage due to that it is very susceptible to deteriorate easily. This results loss of economy due to quality loss. (Abano \& Sam, 2011), such losses are the major challenges for tropical products including the banana especially in Pakistan. It is therefore of great importance to preserve these fruits at least a little longer, and this is made possible through drying and/or dehydration to reduce the moisture to the possible minimum level. Drying is the oldest method of food preservation that is used to extend the shelf life and preserve the product quality, flavor, aroma, color and structure. During drying banana like fruit having high sugar content needs high temperature and long time to reach the safe moisture content. This may cause losses in flavor, color, nutrients and reduces bulk density and rehydration capacity of final product (Tavakolipour, 2009). Drying is an energy rigorous unit process that helps to lower the moisture content of the food being dried to reduce contamination by microorganisms (Rak et al., 2003). Hot air-drying techniques are developed to increase the hygienic and economic importance of the products (Das et al., 2004). Studies have also shown that 10-20\% reduction in moisture can prevent the food from spoilage caused by bacteria, yeast, mold and enzymes, and the flavor and most of the nutritional value are also preserved (Dennis, 1999). The foods are dried to remove moisture at a temperature that does not affect the color, flavor and texture of the food. The initial low temperature during drying process results in the growth of micro-organisms before the food is dried properly. The high temperature and low humidity may result in the surface harden foods. Temperatures of 60 to $70^{\circ} \mathrm{C}$ may inactivate enzymes and check the bacterial growth, while temperatures around $43^{\circ} \mathrm{C}$ are recommended for solar dryers (Kendall \& Allen, 1998). As the banana is considered as highly perishable and bulky fruit, therefore needs stable and convenient form of processing. This makes their transportation distant and export markets costly; this suggests a need to process the bananas into shelf-stable, convenient and less bulky products. Drying process results in substantial reduction in weight and volume; that results in minimum packaging, storage and transportation charge and facilitates storability of the product under ambient temperature especially in developing countries (Kendall \& Allen, 1998). Dried bananas are high in fiber and carbohydrates and low in fat, that make them food of healthy choice. Dehydration has been familiar method to reduce bulk and preserve the bananas and extend its shelf life (Pekke et al., 2001). Food dehydration is a complex process that is influenced by numerous factors (chemical composition of the product, conditions and techniques of drying, immersion medium composition, range of temperature, etc.), which play a major role on the quality attributes of the final product. The nature and level of pre-treatment on rehydration 
characteristics of different fruits are also reported earlier (Kaymak \& Ertekin, 2002). Cabinet dehydration is used to remove the bulk of water present in the fruit or vegetable. As the quality of different dried products can be enhanced by implementation of different treatments (Karim, 2005). Therefore, there is dire need to process fruits with certain pretreatments before the drying operation, because they prevent browning and darkening of the fruit and minimize the unpleasant changes that occur during drying and subsequent storage. They also stop the metabolism of cut tissue by injuring enzymatic routes (Lewick \& Gupta, 1995). Considering above facts, the aims of this study was to evaluate the effects of different pretreatment methods (ascorbic acid, salt solution, lemon juice, and honey dip) on the physic-chemical characteristics and sensory qualities of dried ripe banana slices.

\section{MATERIALS AND METHODS}

\subsection{Sample collection}

Fresh ripe banana (variety Basarai) samples were collected from the local fruits and vegetables market of Hyderabad, Sindh, Pakistan. The samples were brought to the food processing laboratory, Institute of Food Sciences and Technology, Sindh Agriculture University, Tandojam. Pakistan.

\subsection{Sample preparation}

The banana fruits were washed, weighed and manually peeled by hand and sliced with stainless steel knife. The banana slices $5 \mathrm{~mm}$ and $7 \mathrm{~mm}$ were pretreated with four solution including ascorbic acid, salt solution, lemon juice, and honey dip. All treatments were performed in triplicate. Ascorbic acid $3000 \mathrm{mg}$ was dissolved in 660 $\mathrm{mL}$ of distilled water following the method described by Abano \& Sam, (2011). Similarly, sodium chloride 7.25 $\mathrm{g}$ was dissolved in $660 \mathrm{~mL}$ of distilled water, to make salt solution. The $255 \mathrm{~mL}$ of lemon juice was mixed with $255 \mathrm{~mL}$ of distilled water and finally, honey water solution was prepared by using $25 \mathrm{~g}$ of honey dissolved in $100 \mathrm{~mL}$ distilled water (Andress \& Harrison, 2006). About $120 \mathrm{~g}$ of each sample was weighted for the application of pretreatment in each solution for $10 \mathrm{~min}$ after the pretreatment that were subjected for drying. Untreated sample was observed as control to compare the differences among all treatments.

\subsection{Cabinet dehydration}

The pretreated samples of banana slices were placed on the trays for dehydration at the temperatures of 60 to $70{ }^{\circ} \mathrm{C}$ for 12 to $16 \mathrm{hr}$ duration till dehydrate. The dried samples were packed into a transparent labelled polyethylene bag for physico chemical and sensory analysis.

\subsection{Physico-Chemical analysis}

The standard method (AOAC, 2000) was used for moisture percentage determination, ash percentage and vitamin C. The method described by Onwuka (2005) was used for the physiochemical analysis of the fresh and dried banana samples and the parameters were determined as follows: total soluble solids (TSS), pH, total titratable acidity (TTA) and total sugar.

\subsection{Sensory evaluation of dried banana slices}

The sensory evaluation of each sample was performed at $2^{\text {nd }}, 4^{\text {th }}$ and $6^{\text {th }}$ day during storage, the samples were served to a sensory panel, which consisted of eight trained faculty and staff members of Institute of Food Sciences and Technology, Sindh Agriculture University Tandojam. The samples were assessed for sensory attributes of color, flavor, taste, texture, and overall acceptability. The freshly processed banana slices were evaluated using 9- point hedonic scale (Chen et al., 2010) with modification. The panelists score 9 for extremely like and 1 for extremely dislike.

\subsection{Statistical Analysis}

The data obtained were analyzed by statistical tools using Minitab 18 statistical program for one way analysis of variance (ANOVA) and (Steel et al. 1997). All measurements were performed threefold and findings are stated as mean \pm standard deviations.

\section{RESULTS AND DISCUSSIONS}

\subsection{Physico- chemical characteristics of dried banana slices}

The physico chemical characteristics of dried banana slices $5 \mathrm{~mm}$ were observed and results are presented in Table 1. The highest moisture $7.23 \%$ was found in salt solution treated samples as compared to control as untreated $5.96 \%$. These values fall within the safe storage moisture content for dried fruits observed by Abano et al. (2011) and Taiwo et al.(2002), who studied the effect of pre-drying treatments on quality characteristics of tomato slices. The various techniques have been introduced to preserve the perishable fruits and vegetable for their utilization round the year. The ash percentage of pretreated slices showed significant difference and $\mathrm{pH}$ 
value of dried banana slices $5 \mathrm{~mm}$ shown in Table1. The samples in different groups was at significant difference at probability $\mathrm{P}<0.01$ level. The highest $5.97 \mathrm{pH}$ value was observed in the salt solution treatment as compared to control 5.91 and lowest $\mathrm{pH}$ value of 5.26 was observed in banana slices treated with honey. The total soluble solids $6.53{ }^{\circ}$ Brix were highest in salt solution treatment as compared to control $5.53{ }^{\circ}$ Brix. Dried banana slices treated with lemon juice showed $6.48^{\circ}$ Brix, and the banana slices treated with honey has the lowest TSS 5.37 ${ }^{\circ}$ Brix. The total acidity $0.47 \%$ was higher in salt solution treatment as compared to control $0.41 \%$. The lowest $0.40 \%$ total acidity was recorded in honey treated slices $\mathrm{P}<0.01$. Acids stimulate the nutritive value of food as well as recover its sweetness and it also employs the product quality including; flavor, brightness of color, stability, consistency (Adedeji et al., 2011).

The highest total sugar $7.47 \%$ was recorded in control followed by banana slices treated with honey $4.16 \%$. Dried banana slices showed 3.75, 3.03 and 2.62 total sugar when solution of ascorbic acid, lemon juice and salt respectively applied. Treatments of ascorbic acid, lemon juice and salt solution given 3.75, 3.03 and $2.62 \%$ total sugar in dried banana slices respectively. Vitamin $\mathrm{C}$ content $85.97 \mathrm{mg} / 100 \mathrm{~g}$ was observed highest in salt solution treated dried banana slices as compared to control $66.95 \mathrm{mg} / 100 \mathrm{~g}$. These findings are in agreement with the findings of Ogbonna et al. (2013). Dried banana slices treated with lemon juice showed $85.15 \mathrm{mg} / 100 \mathrm{~g}$, whereas, 83.63 and $83.5 \mathrm{mg} / 100 \mathrm{~g}$ was observed in banana slices treated with ascorbic acid and honey respectively.

Effect of different pretreatments on Physico chemical characteristics of dried bananas slice with the thickness of $7 \mathrm{~mm}$ are presented in Table 2 . The moisture $\%$ of the fresh ripe bananas samples was found to be highest $6.89 \%$, further it was observed in dried banana slices treated with salt solution as compared to control which showed $4.92 \%$ moisture content. The moisture content obtained is fall in the range of $4.92-6.89 \%$, that is good for storage of dried fruit products (Mccance , 2002). However, dried banana slices treated with ascorbic acid have highest moisture content $5.56 \%$, whereas, banana slices treated with lemon juice was ranked $3^{\text {rd }}$ in the treatments which showed $5.19 \%$ moisture content. The result $4.81 \%$ was observed in banana slices treated with honey as compared with control samples. The results indicated that highest ash content $8.16 \%$ was observed in salt solution treatment as compared to control which was recorded $6.41 \%$. Whereas, the lowest $8.01 \%$ ash content was recorded in the dried banana slices treated with lemon juice. The banana slices treated with ascorbic acid was ranked $3^{\text {rd }}$ in the treatments. Which showed $7.56 \%$ high ash content in banana slice treated with honey. While banana slices treated with honey recorded lowest $6.60 \%$ ash content as compared to control.

The highest $\mathrm{pH} 6.08$ was observed in salt solution as compared to control which was recorded 5.54. However, the dried banana slices treated with Lemon juice showed 6.03. Whereas, banana slices were treated with ascorbic acid was ranked $3^{\text {rd }}$ in the treatments with $\mathrm{pH}$ of 6.02 . However, banana slices treated with honey showed lowest $\mathrm{pH}$ 5.94. The highest total soluble solids $6.25^{\circ}$ Brix were recorded in salt solution treatment as compared to control which was recorded $5.39^{\circ}$ Brix. However, the dried banana slices treated with Lemon juice showed $6.22{ }^{\circ}$ Brix total soluble solids. Whereas, banana slices treated with ascorbic acid was ranked $3^{\text {rd }}$ in the treatments with $6.09{ }^{\circ}$ Brix. However, banana slices treated with honey $5.41^{\circ}$ Brix was observed lowest in total soluble solids among all the treatments.

The result obtained for total acidity $0.52 \%$ was observed in salt solution treatment as compared to control which was recorded $0.37 \%$. However, the dried banana slices treated with lemon juice showed $0.46 \%$. While banana slices treated with ascorbic acid ranked $3^{\text {rd }}$ in the treatments with $0.45 \%$. Nevertheless, the lowest total acidity $0.41 \%$ was recorded in honey. The data showed that the highest total sugar $6.72 \%$ was observed in salt solution treatment as compared to control which was $2.22 \%$. However, the dried banana slices treated with lemon juice showed $6.47 \%$. Whereas, banana slices treated with ascorbic acid was ranked $3^{\text {rd }}$ in the treatments with $5.06 \%$. However, the lowest total sugar $4.69 \%$ was observed in honey. The results indicated that highest vitamin C $91.35 \mathrm{mg} / 100 \mathrm{~g}$ was observed in salt solution treated slices as compared to control $60.76 \mathrm{mg} / 100 \mathrm{~g}$. However, the dried banana slices treated with lemon juice showed $88.78 \mathrm{mg} / 100 \mathrm{~g}$. Whereas, banana slices treated with ascorbic acid was ranked $3^{\text {rd }}$ in the treatments with $85.89 \mathrm{mg} / 100 \mathrm{~g}$. However, banana slices treated with honey recorded lowest content among all the treatments $85.56 \mathrm{mg} / 100 \mathrm{~g}$. The total soluble solids is one of the important quality parameters in food processing but $55 \%$ sugars can influence the organoleptic properties of the fruit and it was obtained high that is desirable for recovery of processed products and this high value is result of moisture loss by different drying techniques (Adedeji et al., 2006).

The highest total soluble solids $6.25^{\circ}$ Brix were observed in salt solution treatment as compared to control which was recorded $5.39^{\circ}$ Brix. However, the dried banana slices treated with Lemon juice showed $6.22{ }^{\circ}$ Brix total soluble solids. Whereas, banana slices treated with ascorbic acid was ranked $3^{\text {rd }}$ in the treatments with 6.09 ${ }^{\circ}$ Brix. However, banana slices treated with honey $5.41{ }^{\circ}$ Brix was observed lowest in total soluble solids among all the treatments. The data indicated that total acidity $0.52 \%$ was observed in salt solution treatment as compared to control which was recorded $0.37 \%$. However, the dried banana slices treated with lemon juice showed $0.46 \%$. The banana slices treated with ascorbic acid ranked $3^{\text {rd }}$ in the treatments with $0.45 \%$. However, the lowest total acidity $0.41 \%$ was recorded in honey. The data showed that the highest total sugar $6.72 \%$ ) was 
observed in salt solution treatment as compared to control which was $(2.22 \%)$. However, the dried banana slices treated with lemon juice showed $(6.47 \%)$. Whereas, banana slices treated with ascorbic acid was ranked $3^{\text {rd }}$ in the treatments with $(5.06 \%)$. However, the lowest total sugar $(4.69 \%)$ was observed in honey. The results indicated that highest vitamin $\mathrm{C}(91.35 \mathrm{mg} / 100 \mathrm{~g})$ was observed in salt solution treated slices as compared to control $60.76 \mathrm{mg} / 100 \mathrm{~g})$. However, the dried banana slices treated with lemon juice showed $(88.78 \mathrm{mg} / 100 \mathrm{~g})$. While, banana slices treated with ascorbic acid was ranked $3^{\text {rd }}$ in the treatments with $(85.89 \mathrm{mg} / 100 \mathrm{~g})$. However, banana slices treated with honey recorded was lowest among all the treatments $(85.56 \mathrm{mg} / 100 \mathrm{~g})$.

\subsection{Sensory evaluation of dried banana slices}

The results of sensory evaluations are depicted in Figure1. The result presented that color score of banana slices pre-treated with honey scored 6.3, color of slices in control untreated samples scored 5.1. The color rating for slices pre-treated with lemon juice and ascorbic acid was 4.5 and 3.3, respectively, while lowest score 2.8 was observed in banana slices pre-treated with salt solution. The dried banana color difference observed in this study maybe due to the varietal difference, pretreatment methods and different drying conditions. However, Garcia et al. (1998) reported ineffectiveness of sodium bisulphate on the color of dried bananas. Similarly, Boudhrioua et al. (2002) observed that discoloration of raw and ripe bananas dried at $60^{\circ} \mathrm{C}$ air temperature may be prevented using sodium pyrophosphate pretreatments and blanching. In another study, Ranken et al. (2002) used 1:1 ratio of ascorbic-citric acid solution as a chemical treatment to prevent discoloration of dried banana heated at 40 to $70{ }^{\circ} \mathrm{C}$ temperature. The highest score 7.8 for taste was observed in honey treated dried banana slice samples, followed by control sample with score of 5.3, respectively. Banana slices pre-treated with ascorbic acid and lemon juice received score of 3.5 and 3.3, respectively; while the lowest 3.0 score was observed to the slices pretreated with salt solution. These results are further supported by Wander et al. (2004). The results observed were compared with the study carried on sensory evaluation of dried banana slices determining the overall product acceptance, and overall consumer acceptance tastes scores 5.46 and 7.23. The result of color and texture of the banana slice samples were observed according to the work done by Falade et al. (2005), who reported that most of the physicochemical properties increased with drying except moisture content in banana slices whereas, Kaddumukasa et al. (2005) assessed the color, taste, texture and overall acceptability. The physico chemical parameters including specific gravity, solubility and sugar content in dried banana slices were also of significance to this study. The several methods were used to evaluate the texture of samples. Slice texture was the best in pretreated samples with honey scored 6.1, followed by slices of control samples 4.6, pretreated with ascorbic acid 4.0 and salt solution scored 3.3 and the minimum score 3.1 was observed to slices pretreated with lemon juice. No significant difference was observed in texture of banana slices at the probability $\mathrm{P}>0.05$ level. The score for overall acceptability of dried banana slices was scored 6.6 in slices pretreated with honey, followed by slices in control scored 5, lemon juice 4.3, ascorbic acid 3.6 and salt solution treated samples scored 3.0. Statistically differences in overall acceptability were non-significant $(\mathrm{P}>0.05)$ and significant $(\mathrm{P}<0.05)$ in all treated banana slices while compared with those pretreated with honey.

Mean scores for sensory evaluation of dried bananas shown in Figure 2. The analysis of variance suggested significant at $\mathrm{P}<0.05$ level on the color of dried banana slices. The color of $7 \mathrm{~mm}$ cut banana slices pretreated with honey scored 5.8, followed by slices in control samples 4.3 scored. The color rating for slices pre-treated with lemon juice and ascorbic acid was 3.5 and 3.0, respectively, while the lowest score 2.6 was obtained by slices pretreated with salt solution. The flavor score of dried bananas showed significant difference at $\mathrm{P}<0.05$ level effect of pre-treatments on flavor of $7 \mathrm{~mm}$ slices. The highest score (6.0) was given to honey treated slices. Whereas, control samples scored 3.8. The aroma rating for slices pretreated with ascorbic acid and lemon juice scored 3.6 to 3.1, respectively. The lowest score of 2.8 was obtained by slices pretreated with salt solution. The result of taste of dried banana slices $7 \mathrm{~mm}$ was observed statistically significant $(\mathrm{P}<0.05)$. The taste score of 5.1 for was obtained in honey treated slices, and the slices in control group scored 4.1whereas, 3.8 to 3.3 score observed ascorbic acid and salt solution treated samples. The texture score of dried banana slices showed statistically significant $(\mathrm{P}<0.05)$ difference in texture of samples with different pretreatments applied.

The highest texture of banana slices scored 5.8, when pretreated with honey, followed by control 4.1, pretreated with salt solution 4.5, ascorbic acid 3.5 and lemon juice 3.1. The data showed statistically nonsignificant differences in texture of treated banana slices. Whereas, the significant difference was observed with pretreated sample with honey. The result of overall acceptability score of dried banana slices was observed statistically significant $(\mathrm{P}<0.05)$ for $7 \mathrm{~mm}$ dried banana slices. Whereas, the lowest score was observed in dried banana slices pretreated with salt solution scored 3.1. Other studies have also found that increasing temperature caused the deterioration of color and aroma, and physio chemical analysis showed increasing trend with drying time of the slices. In another similar investigation performed by Zhuang et al. (2004) reported that the parameters had remarkable influences on both quality and output of drying banana slice. It is also found that dried banana slices were higher in most of the physico chemical characteristics than the fresh slices except moisture content. 


\section{Conclusions}

It is concluded from the present study that application of pretreatment methods plays significant role in the quality of dried banana slices. It is shown that the effect of pre-treatment methods on moisture, ash, total acidity, total sugar and vitamin $\mathrm{C}$ was significant $(\mathrm{P}<0.05)$, while non-significant $(\mathrm{P}>0.05)$ for $\mathrm{pH}$ and total soluble solids. The banana slices pretreated with honey observed good characteristics for all the sensory evaluation parameters. However, most of the physico- chemical characteristics were higher in salt solution pretreated slices, but their color, flavor, taste, texture and overall acceptability could not get higher score. Consequently, based on these results, the final product of banana slice may have great potential application on commercial scale as raw product or as an ingredient that can be used in baby foods.

5. Conflicts of Interests: -The authors declare that there are no conflicts of interests regarding the publication of this paper.

\section{References}

Abano, E. E. \& Sam, A.L.K. (2011). Effect of different pretreatments and drying characteristics of banana slices. ARPN J. Engg. Appl. Sci, 6(3): 121-129.

Adedeji, A. A. ,Gachovka, T. K. Ngadi, ,M. O. \& Raghavan, G. S. V. (2006). Effect of pretreatment on the drying characteristics of okra. Dry. Tech. 26:1251-1256.

Andress E.L. \& Harrison, J. A. (2006). So Easy to preserve cooperative extension service bulletin $989,5^{\text {th }}$ Edition. The University of Georgia,

AOAC. (2000). Official methods of analysis international. $17^{\text {th }}$ edition. association of official analytical chemists. Washington, USA.

Boudhrioua, N., Michon, C., Carelier, G. \& Borazz, C. (2002). Influence of ripeness and temperature on changes in banana texture during drying. J. Food Eng. 55: 115-127.

Brett A, Cox, D. R. S., Simmons, R. \& Anstee. G. (1996). Producing solar dried fruits and vegetables for micro and small-scale rural enterprise development. Handbook 3: Practical aspects of processing. Chatham, NRI, UK.

Chen, Z., Zhu, C., Zhang, Y., Niu, D., \& Du, J. (2010). Effect of aqueous chlorine dioxide treatment on enzymatic browning and shelf-life of fresh-cut asparagus lettuce. Postharvest Bio. \& Tec. 58: 232-238.

Dalgleish, J. N. \& Andy, N. M. (1988). Dehydration and dried products. Food industries manual.

Das, I., Das, S. K. \& Bal, S. (2004). Specific energy and quality aspects of infrared (IR) dried parboiled rice. J. Food Eng. 62: 9-14.

Dennis, S. (1999). Improving solar food dryers; extracted from home power magazine. (69): 24-34.

Falade, K. O. \&Awoyele, O.O. (2005). Adsorption isotherms and heat of sorption of fresh and promoted oven dried bananas. J. Food Agri. Env. 3 (1): 97-102.

Garcia, R., Leal, F., Rolz, C. (1998). Drying of bananas using microwave and air ovens. J. Food Sci. Tech. 23: 73-80.

GOP. (2011). Economic survey of Pakistan. (2010-2011). Government of Pakistan, economic advisors wing. ministry of finance, Islamabad Pakistan.

GómezLópez, V., Ragaert, P., Jeyachchandran, V., Debevere, J. \& Devlieghere, F. (2008). Shelf life of minimally processed lettuce and cabbage treated with gaseous chlorine dioxide and cysteine. Inter. J Food Micro. 121: 74-83.

Huang, X. \& Hsieh, F. H. (2005). Physical properties, sensory attributes and consumer preference of pear fruit leather. J. Food Eng. 100 (2):254-260.

Kaddumukasa, P., Kyamuhangire, W., Muyonga, J. \& Muranga, F. I. (2005). The effect of drying methods on quality of green banana flour. African crop science conference proceeding, Vol. 7. Pp. 1267-1217.

Karim, O. R. (2005). Effect of pre-treatment on drying kinetics and quality attributes of air dehydrated pineapple slices. Ph.D. Thesis, University Of Agriculture, Abeokuta, Ogun State, Nigeria.

Kaymak, F. (2002). Drying and rehydrating kinetics of green and red peppers. J. Food Sci., 67(1): 168-175.

Kendall, P. \& Allen, L. (1998). Drying vegetables: Food and nutrition series-preparation.colorado state university cooperative extension service publication $10 / 1998$.

Lewicki, P. P.\& Das, Gupta, D. K. (1995). Osmotic dehydration of fruits and vegetables in handbook of industrial drying, Vol. 1, 2nd Edition, Ed. A.S. Mujumdar, Marcel Dekker, New York, Pp. 691-713.

Mazumdar B. C. \& Majumder, K. (2003). Methods on Physico- chemical analysis of fruits. University College of Agriculture, Calcutta. 108-109.

Mcminn, W. A. M. \& Magee, T. R. A. (1997). Physical characteristics of dehydrated potatoes. J. Food Eng., 33(1-2): 37-48.

Mccance. (2002). The Composition of foods. $6^{\text {th }}$ Edn. The Royal Soci. of Chem, Cambridge.

Menges \& Ertekin, C. (2006). Mathematical modeling of thin layer drying of golden apples. J. Food Eng. 77 : 119-125. 
Ogbonna, A. C., Abuajah, C. I., Ekpe, G. E. (2013).A comparative study of the nutritive factors and sensory acceptance of Juices From Selected Nigerian fruits. crop. J. Food Tech. Biotech. Nutr.8 (1-2): 47-51.

Onwuka, G. I. (2005). Food analysis and instrumentation: Theory and Practice, $1^{\text {st }}$ Edition, Naphtali Print, Lagos, Nigeria, 133-137.

Pellegrini, H. D. E., Stefan, E. \& Ronco, A. (1996). Vegetables, fruits, and risk of colorectal cancer: a casecontrol study from Uruguay. Nutr. Cancer 25 (3): 297-304.

Pekke, M., Nowakunda, K., \& Tushemereirwe, W. (2001). Overview of banana utilization in east Africa.

Pomeranz, Y. \& Meloan, C. E. (2000). Food analysis. Theory and practice, $3^{\text {rd }}$ edition, Aspan publishers, Gaithersbury Maryland, 416.

Rak, D., Richard, M. \& Gordon, Y. (2003). The effect of pretreatments on the drying rate and quality of dried bananas. Inter. J. Food Sci. Tech. 38: 877-882.

Ranken , M. D., Blackie, G., Dandamrongrak, R., Young, G. \& Mason, R. (2002). Evaluation of various pretreatments for the dehydration of banana and selection of suitable drying models. J. Food Eng. 55:139-146.

Renu, K. M., Shukl, R. N. \& Joshi, T. (2012). Mass transfer during osmotic dehydration of banana slices for drying process, Inter. J. Sci. Res Pub. 2 (7): 2250-3153.

Senadeera, W., Bhandari, B. R., Young, G. \& Wijesinghe, B. (2005). Modeling dimensional shrinkage of shaped foods in fluidized bed drying. J. Food Process. Pres. 29: 109-119.

Sharareh, M. \& Reihaneh, A. G. (2011). Effect of pre-drying treatments on quality characteristics of dehydrated tomato slices. World Academy of Science, Engineering and Technology 59.

Tavakolipour, H. (2009). Drying of food materials and agricultural products, third edition, Aeezh publishing company, Tehran (In Persian).

Taiwo, K. A., Angersbach, A. \& Knor, D. (2002). Rehydration studies on pretreated and osmotically dehydrated banana slices. J. Food Sci. 67(2): 112-116.

Wander, A., Sousa, A. \& Marsaioli, J. (2004). Drying of bananas assisted by microwave energy, Sao Paulo, Brazil, Pp. 1946-1954.

Zhuang, Y., Liu, J., Zhong, W., Su, X. \& Wang, Y. (2011). Study on process of banana slice under vacuum freeze-drying. Journal of Zhangzhou Normal University, 6 (1): 239-243.

Table 1 Effect of different pretreatments on physico chemical characteristics of dried bananas (Slice $5 \mathrm{~mm}$ )

\begin{tabular}{|l|l|l|l|l|l|l|l|}
\hline Treatments & $\begin{array}{l}\text { Moisture } \\
(\%)\end{array}$ & Ash $(\%)$ & $\mathrm{pH}$ & $\begin{array}{l}\text { TSS } \\
\left({ }^{\circ} \text { Brix }\right)\end{array}$ & $\begin{array}{l}\text { Total } \\
\text { Acidity } \\
(\%)\end{array}$ & $\begin{array}{l}\text { Total } \\
\text { Sugar }(\%)\end{array}$ & $\begin{array}{l}\text { Vitamin } \\
(\mathrm{mg} / 100 \mathrm{~g})\end{array}$ \\
\hline Fresh & $77.77^{\mathrm{a}}$ & $0.97^{\mathrm{e}}$ & 5.76 & 6.02 & $0.26^{\mathrm{b}}$ & $4.88^{\mathrm{b}}$ & $49.18^{\mathrm{c}}$ \\
\hline Control & $5.96^{\mathrm{bc}}$ & $6.28^{\mathrm{bc}}$ & 5.91 & 5.53 & $0.41^{\mathrm{a}}$ & $7.47^{\mathrm{a}}$ & $66.95^{\mathrm{b}}$ \\
\hline Ascorbic Acid & $4.66^{\mathrm{c}}$ & $5.81^{\mathrm{cd}}$ & 5.75 & 5.79 & $0.42^{\mathrm{a}}$ & $3.75^{\mathrm{cd}}$ & $83.63^{\mathrm{a}}$ \\
\hline Salt Solution & $7.23^{\mathrm{b}}$ & $7.66^{\mathrm{a}}$ & 5.97 & 6.53 & $0.47^{\mathrm{a}}$ & $2.62^{\mathrm{e}}$ & $85.97^{\mathrm{a}}$ \\
\hline Lemon Juice & $6.12^{\mathrm{bc}}$ & $6.56^{\mathrm{b}}$ & 5.87 & 6.48 & $0.45^{\mathrm{a}}$ & $3.03^{\mathrm{de}}$ & $85.15^{\mathrm{a}}$ \\
\hline Honey & $4.60^{\mathrm{c}}$ & $5.56^{\mathrm{d}}$ & 5.26 & 5.37 & $0.40^{\mathrm{a}}$ & $4.16^{\mathrm{bc}}$ & $83.52^{\mathrm{a}}$ \\
\hline
\end{tabular}

Table 2 Effect of different pretreatments on physico-chemical characteristics of dried bananas (Slice 7mm)

\begin{tabular}{|l|l|l|l|l|l|l|l|}
\hline Treatments & $\begin{array}{l}\text { Moisture } \\
(\%)\end{array}$ & Ash $(\%)$ & $\mathrm{pH}$ & $\begin{array}{l}\text { TSS } \\
(\text { Brix })\end{array}$ & $\begin{array}{l}\text { Total } \\
\text { Acidity } \\
(\%)\end{array}$ & $\begin{array}{l}\text { Total } \\
\text { Sugar } \\
(\%)\end{array}$ & $\begin{array}{l}\text { Vitamin C } \\
(\mathrm{mg} / 100 \mathrm{~g})\end{array}$ \\
\hline Fresh & $77.77^{\mathrm{a}}$ & $0.97^{\mathrm{d}}$ & 5.76 & 6.02 & $0.26^{\mathrm{c}}$ & $4.85^{\mathrm{b}}$ & $49.18^{\mathrm{c}}$ \\
\hline Control & $4.92^{\mathrm{c}}$ & $6.41^{\mathrm{c}}$ & 5.54 & 5.39 & $0.37^{\mathrm{bc}}$ & $2.22^{\mathrm{c}}$ & $60.76^{\mathrm{b}}$ \\
\hline Ascorbic Acid & $5.96^{\mathrm{bc}}$ & $7.56^{\mathrm{c}}$ & 6.02 & 6.09 & $0.45^{\mathrm{ab}}$ & $5.06^{\mathrm{b}}$ & $85.89^{\mathrm{a}}$ \\
\hline Salt Solution & $6.89^{\mathrm{b}}$ & $8.16^{\mathrm{a}}$ & 6.08 & 6.25 & $0.52^{\mathrm{a}}$ & $6.72^{\mathrm{a}}$ & $91.35^{\mathrm{a}}$ \\
\hline Lemon Juice & $5.19^{\mathrm{c}}$ & $8.01^{\mathrm{ab}}$ & 6.03 & 6.22 & $0.46^{\mathrm{ab}}$ & $6.47^{\mathrm{a}}$ & $88.78^{\mathrm{a}}$ \\
\hline Honey & $4.81^{\mathrm{c}}$ & $6.60^{\mathrm{c}}$ & 5.94 & 5.41 & $0.41^{\mathrm{ab}}$ & $4.69^{\mathrm{b}}$ & $85.56^{\mathrm{a}}$ \\
\hline
\end{tabular}




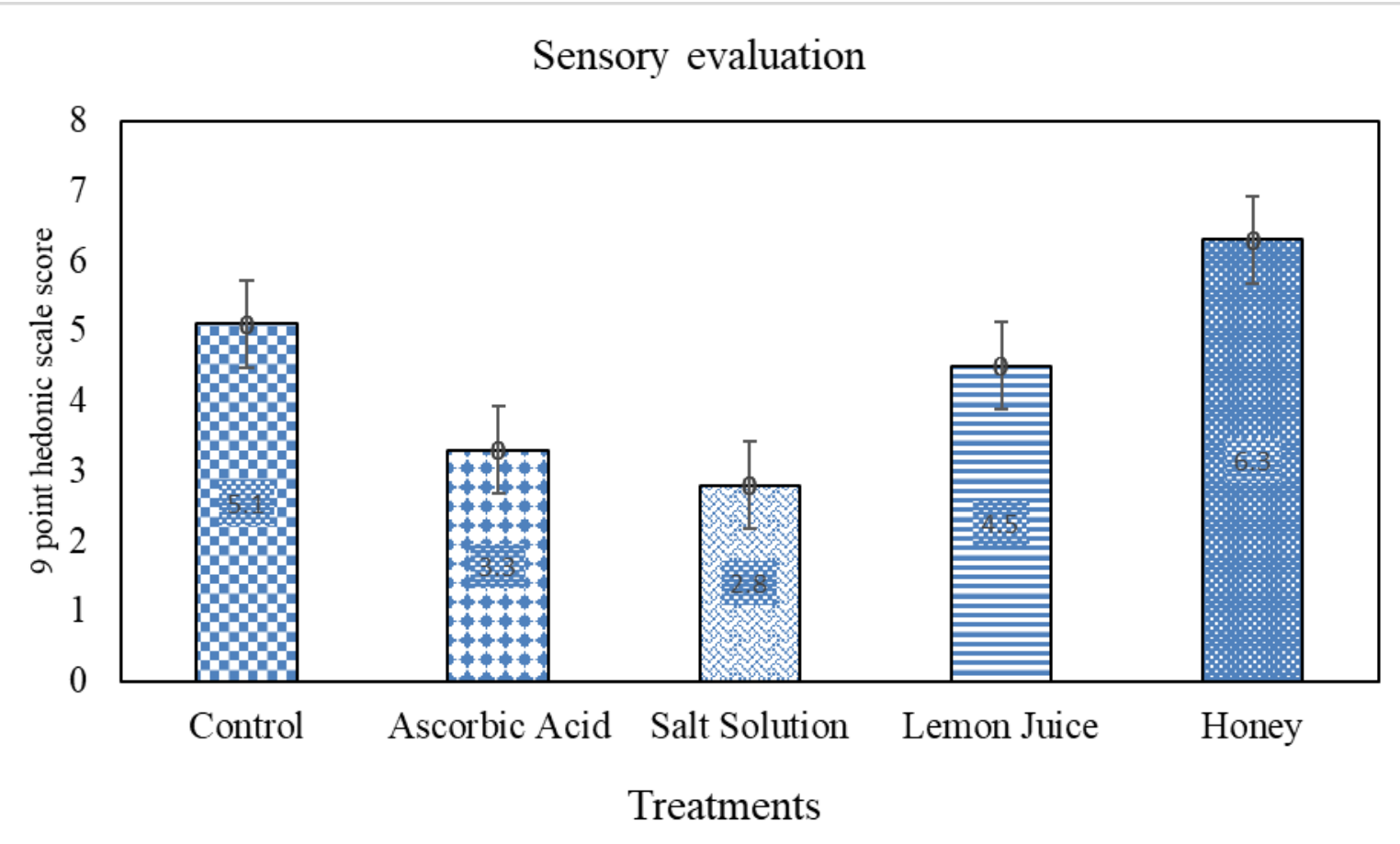

Figure 1 Mean scores for sensory evaluation of pre-treated dried bananas (Slice $5 \mathrm{~mm}$ ) 